\title{
The roles of small RNAs: insights from bacterial quorum sensing
}

\author{
Hongchang $\mathrm{Fu}^{1 *}{ }^{*}$, Rosalía Cardós Elena ${ }^{1}$ and Paola Handal Marquez ${ }^{2}$
}

\begin{abstract}
Ribonucleic acids (RNAs) mainly played auxiliary roles in regulations of genetic processes while recent explorations into small non-coding RNAs (sRNAs) in bacteria have broadened the scope of RNAs studies in these processes. sRNAs have been demonstrated to be involved in various genetic processes and to regulate a variety of bacterial physiologies. Comparatively, quorum sensing (QS) is a mature bacterial cell signaling system which regulates bacteria physiologies as well. Prokaryotic sRNAs studies in the status quo have revealed an emerging picture of trans-kingdom signaling regulation and increasing investigations have demonstrated the feasibility of inter-kingdom signaling as the consequence of QS. We therefore review such phenomena and their similarities to investigate the potential of prokaryote-sourced interkingdom signaling and regulation.
\end{abstract}

Keywords: Small RNA, Quorum sensing, Inter-kingdom communication, Prokaryotes, Eukaryotes, Extracellular microvesicles

\section{Introduction}

The first bacterial sRNA, MicF, was reported and characterised by Takeshi Mizuno and his group in 1984 [1]. It was observed to regulate the translation of trans-membrane protein OmpF in Escherichia coli. More sRNAs were gel separated and identified in 1999 [2]. Facilitated by computational analysis, many groups initiated genome-wide searches $[3,4]$ for sRNAs in the next few years [4] and the field of sRNA studies experienced a boom. As this field attracted increasing attention, the study expanded towards eukaryotic cells. Many other concepts stemmed from sRNAs in other kingdoms, e.g. micro RNAs and siRNAs. Nevertheless, all non-coding regulatory RNAs in bacteria are classified as sRNA $[5,6]$.

\section{sRNAs in Bacteria}

These advances provided a solid ground for further characterisation of sRNA. Bacterial sRNAs are 50-500 nucleotide long non-coding RNAs [7, 8]. sRNAs are highly structured due to intramolecular base pairing, forming secondary structures such hairpins and stem loops [8]. Sandra Cristina Viegas with her group

\footnotetext{
* Correspondence: zcbehfu@ucl.ac.uk

${ }^{1}$ Department of Biochemical Engineering, University College London, Bernard Katz Building, Gower Street, London WC1E 6BT, UK

Full list of author information is available at the end of the article
}

proposed that these stem-loops stabilise [8] the sRNA. The gene sequences coding for sRNAs are mainly located in intergenic regions (IGRs) [9]. However, there was one case $[9,10]$ which reported that sRNA genes exist in the 3'UTR region of mRNA genes. sRNAs are transcribed from DNA, in contrast to mRNA, sRNAs are untranslated and usually regulate the translation by interference with mRNA. This concept apparently goes against [11] Francis Crick's Central Dogma of molecular biology [12] because the classical RNA transcripts (mRNA, tRNA and rRNA) [11-13] are translated into proteins whereas sRNAs are not. Gradually, as the field is broadening, this formerly controversial concept is now commonly accepted as an exception of Central Dogma [11, 12].

A variety of approaches have been developed over the past decades to identify and characterise sRNAs. There are either laboratory-based techniques or computational techniques. Northern blotting, as one of the modified gel analysis techniques, identifies sRNAs by sizes. Most of the novel sRNA sequences are predicted and characterised in silico $[14,15]$ such as comparative genomics-based models $[6,14,16,17]$, RNA sequencing $[15,18]$, microarrays [14] and even machine-learning based models [16] in these days.

(c) The Author(s). 2019 Open Access This article is distributed under the terms of the Creative Commons Attribution 4.0 International License (http://creativecommons.org/licenses/by/4.0/), which permits unrestricted use, distribution, and reproduction in any medium, provided you give appropriate credit to the original author(s) and the source, provide a link to the Creative Commons license, and indicate if changes were made. The Creative Commons Public Domain Dedication waiver (http://creativecommons.org/publicdomain/zero/1.0/) applies to the data made available in this article, unless otherwise stated. 
Small RNAs interact with messenger RNAs (mRNAs) to regulate gene expression $[1,8,19-22]$. These RNA regulations are classified into negative regulation [8] and positive regulation [19] by the type of sRNAs, their binding patterns and the extent to which sRNAs impact post-transcriptional process [5]. Negative regulation impacts the level of translation adversely. Its characterized by either true anti-sense or limited-complementary RNAs [5]. Anti-sense RNAs modulate [23] activities of single type of mRNA due to its full complementarities $[5,23,24]$ to the target mRNA sequences. Similarly, limited complementary RNAs bind to the target by complementary base pairing whereas the essential difference between anti-sense and limited complementary is that the latter ones have partial $[5,23]$ complementary sequences to the target mRNA sequence. This feature enables limited complementary sRNAs to target multiple types of mRNA because they only need to have a part of the sequences that is complementary to mRNA sequences. RNA is degraded [5] and the translation is interrupted when the mRNA is bound by anti-sense sRNA. The level of translation is reduced when mRNA is bound by limited-complementary sRNAs. In contrast to negative regulation, positive regulation upregulates the translation. This involves an RNA chaperone protein [25] named Hfq which was firstly discovered [26] as $E$. coli host factor in 1960s. Until recent years has the role of Hfq protein been redefined [19, 24, 27, 28] to either stabilise or destabilise [24] RNAs by causing structural changes to RNA molecules including sRNAs and mRNAs [5].

Wassarman and his group demonstrated $[2,24]$ that, in response to stimuli, sRNAs cofunction with Hfq proteins to upregulate translation of rpoS mRNA [21, 22, 24] by forming sRNA-Hfq complexes. Normally, ribosomal binding site (RBS) of rpoS mRNA is buried in the secondary structure, which inhibits the translation. However, the
sRNA-Hfq complex modifies [19] the structure by exposing RBS (Fig. 1). Ribosomes can therefore bind to RBS and expression increases dramatically.

Current well-documented model bacteria that harbor sRNAs include Escherichia coli [5, 29-31], Salmonella [32], Cyanobacteria, Streptococcus pyogenes [33-35], Pseudomonas aeruginosa [5, 36], Vibrio harveyi [37], Vibrio cholerae [37], Vibrio fischeri [37]. Apart from regulating genetic activities of bacterial species above, sRNA plays a versatile role in regulating bacterial physiologies [23]. These mainly include virulence, outer-membrane regulations and quorum sensing. They are inter-connected and discussed later in this review.

\section{Intra/inter-species and Interkingdom quorum sensing}

Bioluminescence was studied in $V$. harveyi and $V$. fischeri for its ecological effect back at the 1980s [38, 39] while another aspect [40] hidden behind bioluminescence was unraveled. It was observed that only when bacterial cell density reached a threshold would the cells emit light. Light was then associated with enzyme termed luciferase [39] and its Lux operon LuxCDABEG [41-43]. In later investigations, same group found evidence that cell density threshold was in accordance to the concentration of an extracellular molecule [38]. Only if when enough of these molecules [39] were secreted at high cell density would bioluminescence be triggered. This type of molecules was defined as auto-inducers ( $\mathrm{AI}$ ) and this was the first time [41] that scholars proved the existence of bacterial cell communication extracellularly and this AI-associated bacterial 'social behaviour' was named Quorum Sensing (QS) $[38,40,41,44,45]$. For the past decades, from investigating bioluminescence, the scope of studying QS has been expanded towards other group behaviours and it has been confirmed QS regulate bacterial pathogenicity and virulence $[41,42]$.

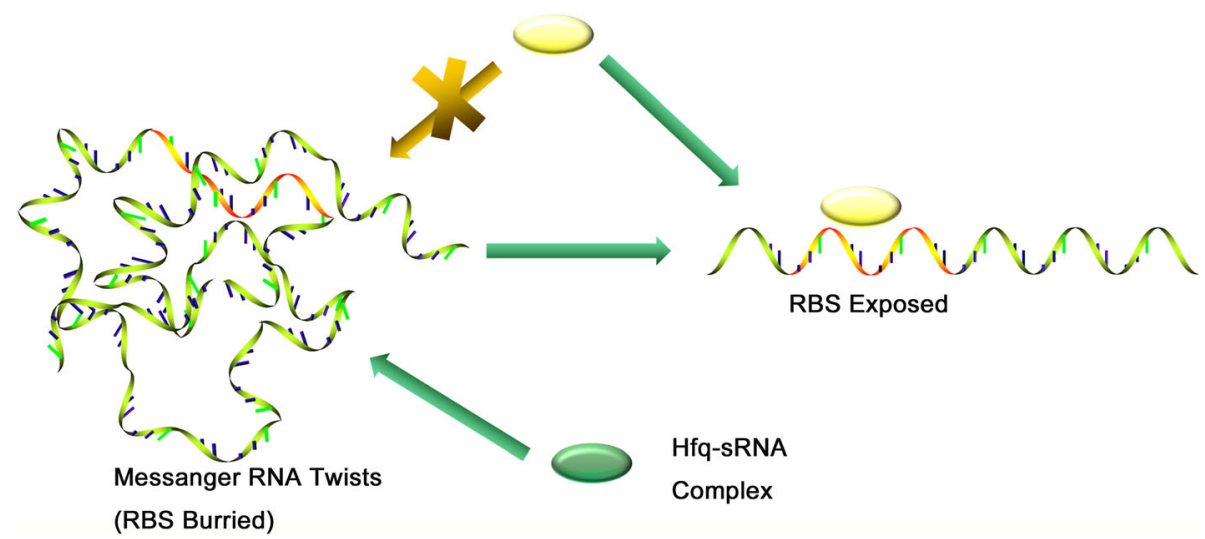

Fig. 1 Action of Hfq-sRNA complex on mRNA. The RBS is buried within the mRNA secondary structure, inhibiting translation. The Hfq-sRNA complex upregulates the translation by interaction with mRNA, exposing the RBS outside by modifying the structure [2, 19, 21, 22, 24] 
Quorum sensing allows a single bacterial cell to sense the number of cells around and exchange information about itself with the rest of cells $[41,42,46]$. Both processes are achieved by AI secretion and a reception. There are two stages for completing a group behaviour such as pathogenicity. Firstly, bacterial cells secret AIs to sense the cell density. AIs then bind to the receptors to trigger the collective behaviour gene. Only if when the population reached a threshold to which the expression of gene causes dramatic influence (e.g. concentration of toxin) will the gene of interest be expressed [46].

All bacterial harbor this machinery to regulate their collective behaviours. Gram-negative and gram-positive bacteria both use QS to regulate subsequent group behaviour although there are subtle variations in type of autoinducers and their mechanisms [41, 42]. In gram-negative bacteria, auto-inducer refers to $\mathrm{N}$-Acyl homoserine lactone derivatives (AHL) [39, 43, 47].

Nonetheless, the functional group (usually fatty acid) ensures the specie-specificity [41] of quorum sensing. Majority of the gram-negative bacteria quorum sensing is regulated by highly conserved LuxR/LuxI family [48] although there are bacteria species like $V$. harveyi, Staphylococcus aureus and Bacillus subtilis which use two-component systems [42, 49, 50, 51]. Generally speaking, in gram-negative bacteria, LuxI synthases synthesise acyl homoserine lactone (AHL) and they diffuse outside the cells [41, 52-54]. AHL molecules diffuse into other cells freely and bind to LuxR receptors in other cells. LuxR protein molecules consist of two domains for DNA binding and autoinducer binding respectively [54]. DNA binding domain is only activated once the autoinducers bind [53]. AHL-bound-LuxR protein complex binds to the promotor and initiates transcription of gene of interest [52]. LuxR regulates transcription of many genes typically bioluminescence, biofilm formation and virulence (Fig. 2). Other species like $P$. aeruginosa (LasI-LasR) [55] uses LuxI-LuxR-type system [41] as well [52]. As mentioned above, there are difference between autoinducers while parent core is identical. This ensures that only intra-species communication is constructed. Gram-positive quorum sensing mainly involves two-component system [41] and the signaling molecule have difference [41] from the one of gram-negatives. Two-component system consists of a sensor kinase and a response regulator [41, 42, 56].Instead of AHL being secreted, precursor proteins are translated from gene followed by a processing step which cleaves precursors into oligopeptides $[41,57]$. These peptides are then secreted out. Two-component system functions when concentration of autoinducer peptides reaches a threshold. Transmembrane sensor kinase receives the signal (AIs) and initiate phosphorylation $[41,56]$. Transcription factor enables the gene transcription as the consequence of response regulator involvement. The general signaling procedures are the same even though the mechanisms are different in gram-positive/negative bacteria.

QS does not only exist at intra-species level but also at inter-species level. Bacteria have their universal language when various bacterial communities co-exist (Fig. 3). Bassler et al. discovered a universal signaling molecule and its according mechanism [41]. This varies from existing signaling mechanism of a bacterial species yet it co-functions with the latter. Bacteria apply either inter-species language or generic language when it is needed to interact internally and externally.

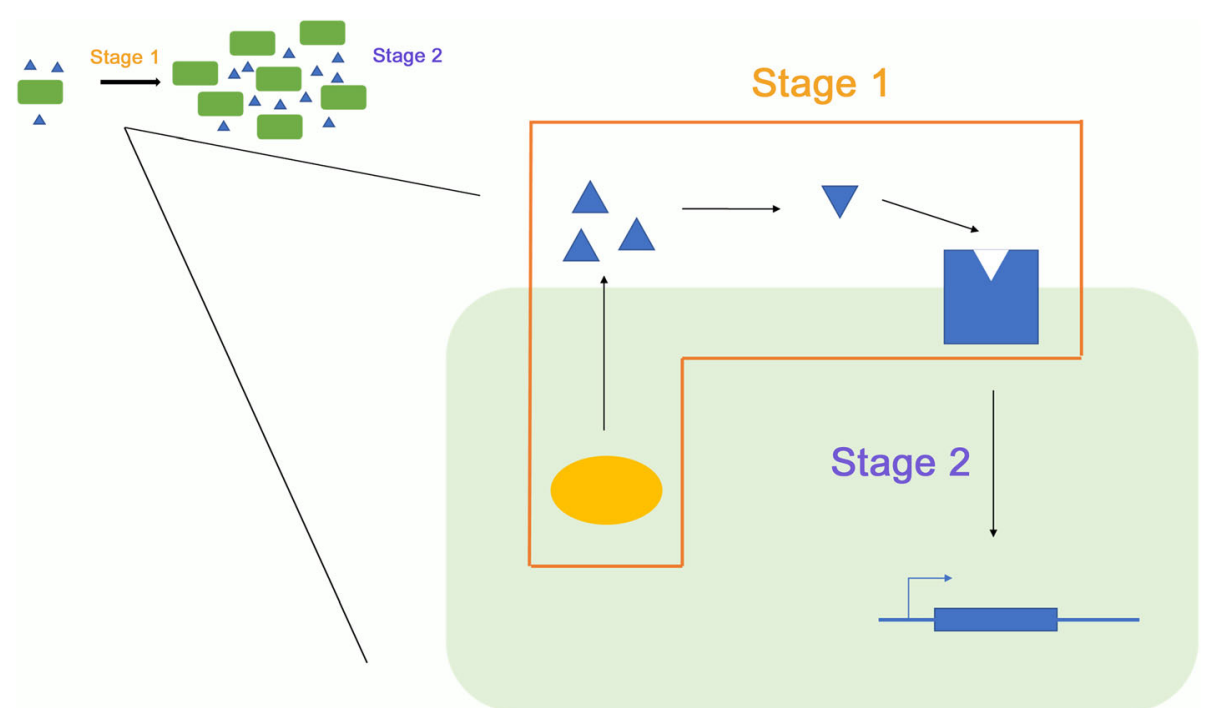

Fig. 2 A brief process of how quorum sensing functions. Stage 1. A single cell secrets Als and other cells sense this signal. Stage 2. Once cell density reaches a threshold, there is sufficient $\mathrm{Al}$ accumulation and gene regulation occurs in the whole population 


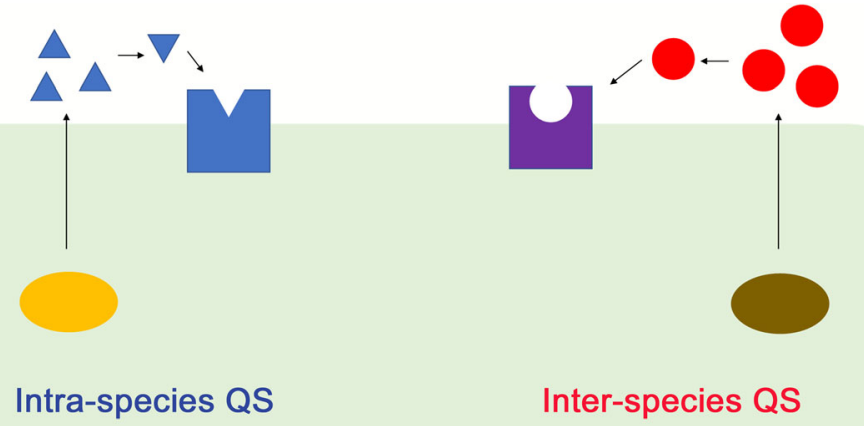

Fig. 3 Two systems for intra/inter-species communication respectively. A single bacterium can have two sets of signaling methods for intraspecies and interspecies communication. The mechanism is identical while the signaling molecule is different between two systems. All discovered bacteria which utilise quorum sensing communicate through the same signaling molecule where inter-species communication is needed

Various cases have demonstrated the existence of interkingdom signaling by QS machineries [58-60]. In, Legionella pneumophila, QS is facilitated by AI LAI-1coded by LqsA. This gram-positive bacterium lives at which its AI affects the same species, but also interacts with its eukaryotic host cells, affecting their migration. LqsA encodes for autoinducers LAI-1 and this autoinducer is transported extracellularly. LAI-1 is uptaken by trans-membrane receptor in host cells and its involved in production of cell migration microtubules [58]. The mechanism of host cell uptaking is unknown and neither does the receptor, whereas it suggested the feasibility of interkingdom communication. Other pro-to-eukaryotic communications have been identified [60]. A typical example of co-functioning is seaweed Enteromorpha and Vibrio anguillarum. Enteromorpha starts the growth based on the biofilm produced by Vibrio anguillarum. As proposed by this group, the growth of seaweed is highly dependent to the concentration of autoinducer from Vibrio anguillarum [60].

\section{Inter-kingdom signaling through sRNA}

QS-mediated interkingdom communication provided an insight of whether or not can sRNA interact with eukaryotic cells for the reason that autoinducer AHL and sRNA both regulate inter-cellular activities at molecular level. The answer is confirmative. There has been a number of evidences showing sRNA interferes with LuxR in quorum sensing [42]. In addition to that, discovery of quorum regulatory RNAs (Qrr) [30, 61], demonstrated sRNA can regulate interkingdom communication. Yet it is not going to be discussed in detail as a directly related communication is arising over the last years [62-65]. Extracellular vesicles (EVs) were initially thought to only exist in eukaryotes [66] and play a critical role in intercellular communication by carrying RNA and proteins $[62,67,68]$. It has also been described that EVs can carry miRNAs and aid in their horizontal transfer [67-70] and that sRNA may be secreted extracellularly by similar means in prokaryotes [63, 69, 71-74]. EVs in prokaryotes are named outer membrane microvesicles (OMVs) [62] since they are released from the outer membrane [75]. Unlike EVs, the exact mechanism of OMV biosynthesis remains unclear. A proposed model is depicted in Fig. 4. First, breakage of peptidoglycan linking proteins bound to both the inner and outer cell membranes is necessary to produce OMVs [76]. Molecules to be bound to OMVs accumulate in the periplasm. Aided by the curvature inducing protein, the outer membrane is curved out $[65,75]$. Eventually the OMVs are formed, blistered out and the outer membrane closes completely [77]. As part of this, sRNA can be packed in OMVs and transported out, yet the mechanism of how sRNAs enter these vesicles is not well understood. OMVs can then enter other cells, including eukaryotes, by membrane fusion $[77,78]$ thus releasing their content, which may include exogenous sRNA. This proposed mechanism has been described in $P$. aeruginosa host-pathogen interactions by Koeppen et al. [79], despite it is not specified how sRNA can affect host cells in this context.

In another example of trans-kingdom cross-talk due to sRNA, sRNA from $E$. coli may hijack the RNAi of $C$. elegans as illustrated in Fig. 5. A protein similar to $\mathrm{Hfq}$, RDE-2 [78], is endogenous to C. elegans but may bind to $E$. coli sRNAs, resulting in post-transcriptional silencing [78].

In addition to these unidirectional interkingdom communications, recent research has related gut microbiota to sRNA. It has been depicted that eukaryotic cells can respond and interact with bacteria in gut through miRNA [80, 81]. Subsequently, the interactions between these two communities may even have impact on brain through the gut-brain axis [81] even though this observation was not systematically assessed. A similar 


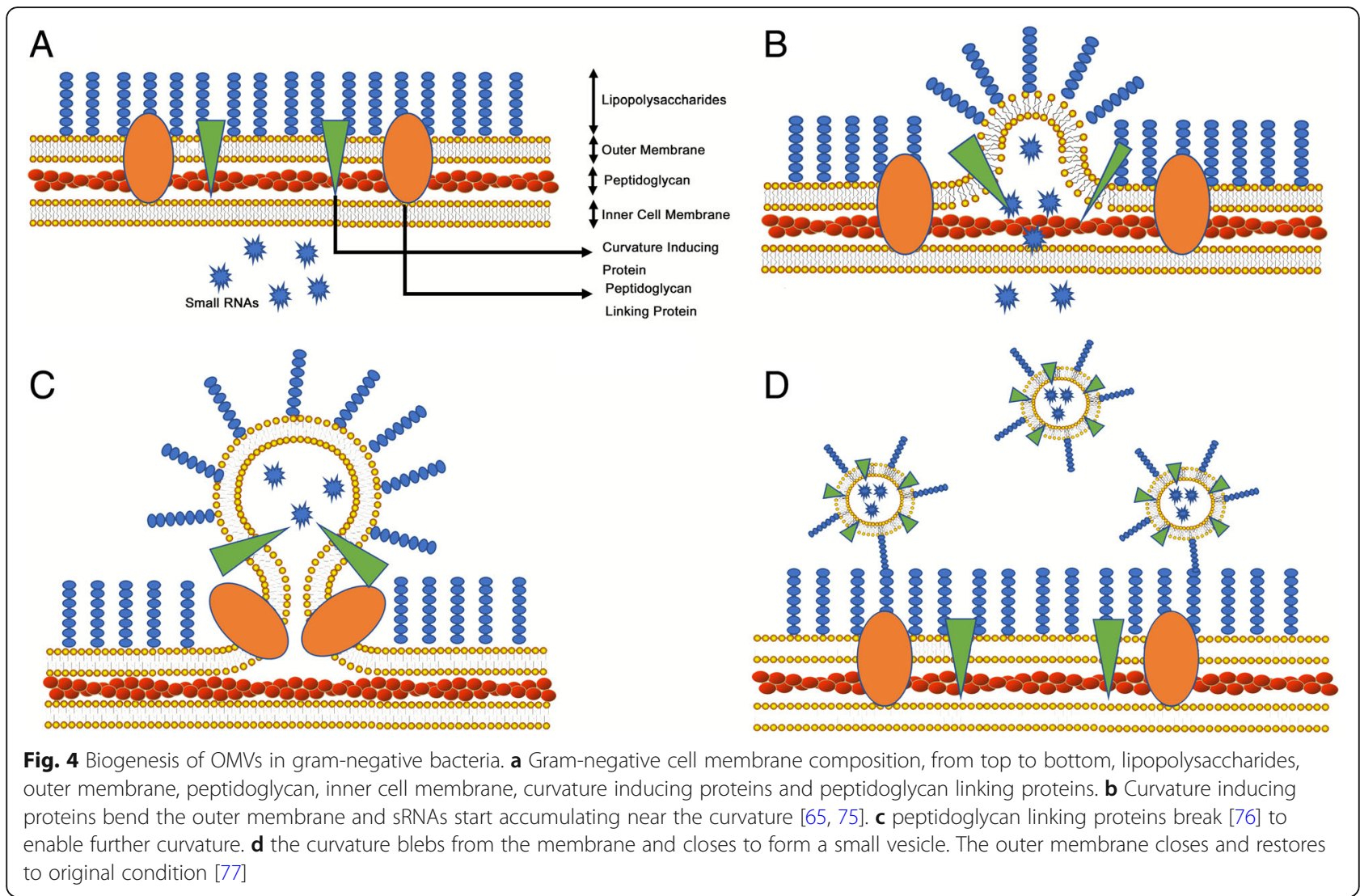

phenomenon [82] has also been reported by other groups on cooperation of intestinal microbiota with eukaryotic miRNA response to counter against the Listeria infection in gut [83].

\section{Conclusions and prospective}

Even though there has not been solid evidence showing direct accordance between QS and sRNA interkingdom regulations, it is thought that the QS does have impact on extracellular journey of sRNAs. sRNAs concentration decreases when sRNAS enter target cells although they are described to be resistant to harsh environments. sRNAs may be degraded by target cells defenses like by target cell defences such as RNAses. Bacterial QS may assist against reduction on concentration of sRNAs by raising the threshold of sRNA concentration and secrete more of them before entering target cells so that enough of them can interfere with target cell mRNAs.

The impact on sRNA on bacterial intercellular physiology and the mechanism of QS at both an inter-species and inter-kingdom level are well understood. With recent advances in OMVs studies in prokaryotes, we see the tip of the iceberg of interkingdom communication directly through sRNAs. Yet the mechanisms of how sRNAs are accumulated for EVs enrichment, how these vesicles selectively travel from prokaryotic to eukaryotic cells and how sRNAs hijack the target cell machineries without being degraded are left unclear and to be unveiled.

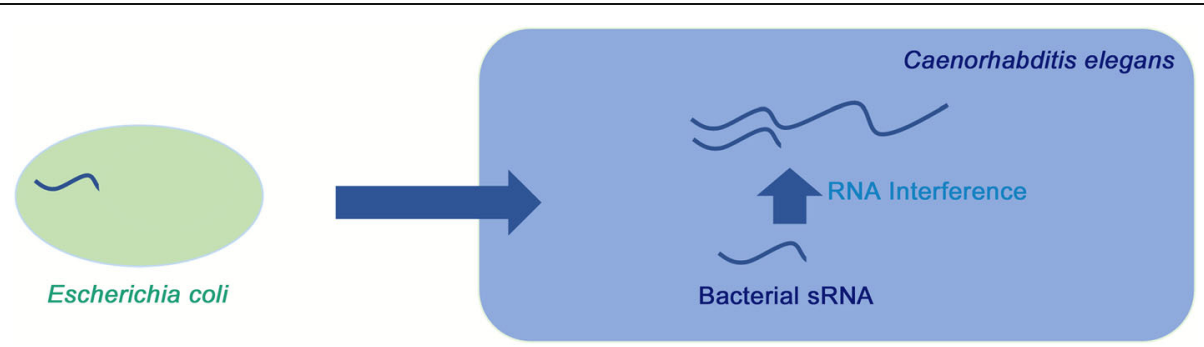

Fig. 5 An example of inter-kingdom communication through sRNA. E. coli alters the foraging behaviours of C. elegans by transporting sRNAs into C. elegans. Exogenous bacterial sRNAs then hijack the RNAi machineries in C. elegans [78] 
This may hint at how sRNAs can be exploited for several applications. With the aid of computational analysis like comparative genomics [84], sRNA-based gene therapy in cancer treatment is feasible. Given the mRNA sequence of the carcinogenic proteins, a target-based therapeutic sRNA can be found and synthesised [85]. Small RNA can then be delivered into target cells using OMVs as vector, silence these cancer-related gene expressions and disrupt the cancer cell physiologies $[82,84,85]$. Additionally, it is noteworthy pointing out another potential therapy based on gut-brain axis due to the observation described above. The consequence of microbiota-gut interaction [82] subsequently affects the brain development, which indicate the possibility of sRNA-based therapy [85] to potentially delivery drugs $[81,82]$ or cure the neural diseases by gut-brain axis as it passes the blood-brain barrier.

\section{Abbreviations \\ AHL: Acyl homoserine lactone; Al: Autoinducer; DNA: Deoxyribonucleic acid; EV: Extracellular vesicle; IGR: Intergenic regions; miRNA: Micro ribonucleic acid; mRNA: Messenger ribonucleic acid; OmpF: Outer membrane protein $F$ OMV: Outer membrane vesicle; QS: Quorum sensing; RBS: Ribosomal binding site; RNA: Ribonucleic acid; RNAi: Ribonucleic acid interfering; rRNA: Ribosomal ribonucleic acid; siRNA: Small interfering ribonucleic acid; sRNA: Small ribonucleic acid; tRNA: Transfer ribonucleic acid; UTR: Untranslated region}

\section{Acknowledgements}

Many thanks to G. Lu, J. Han, K. Achirri, M. Liu, W. Sun, Y. Liu, Y. Sun and Z. Fu for insights, discussions and for helpful comments in writing this review. Special thanks to R. C for great help and comments in edition of the manuscripts.

\section{Funding}

Not applicable.

\section{Availability of data and materials}

Not applicable.

\section{Authors' contributions}

HF drafted the manuscript. RC contributed to review and made a number of valuable comments to the manuscript. PH commented the review and corrected the grammatical error. All authors read and approved the final manuscript.

\section{Ethics approval and consent to participate}

Not applicable.

\section{Consent for publication}

Not applicable.

\section{Competing interests}

The authors declare that they have no competing interests.

\section{Publisher's Note}

Springer Nature remains neutral with regard to jurisdictional claims in published maps and institutional affiliations.

\section{Author details}

'Department of Biochemical Engineering, University College London, Bernard Katz Building, Gower Street, London WC1E 6BT, UK. ${ }^{2}$ Institute of Structural and Molecular Biology, Division of Biosciences, University College London, Darwin Building, Gower Street, London WC1E 6BT, UK.
Received: 21 August 2018 Accepted: 15 March 2019

Published online: 09 September 2019

\section{References}

1. Mizuno T, Chou MY, Inouye M. A unique mechanism regulating gene expression: translational inhibition by a complementary RNA transcript (micRNA). Proc Natl Acad Sci U S A. 1984;81(7):1966-70.

2. Wassarman KM, Zhang A, Storz G. Small RNAs in Escherichia coli. Trends Microbiol. 1999; 7(1):37-45

3. Waters LS, Storz G. Regulatory RNAs in Bacteria. Cell. 2009;136(4):615-28.

4. Sharma CM, Vogel J. Experimental approaches for the discovery and characterization of regulatory small RNA. Curr Opin Microbiol. 2009;12(5): $536-46$.

5. Gottesman S. The small RNA regulators of Escherichia coli : roles and mechanisms. Annu Rev Microbiol. 2004;58(1):303-28.

6. Vogel J, Wagner EGH. Target identification of small noncoding RNAs in bacteria. Curr Opin Microbiol. 2007:10(3):262-70.

7. Novick RP, Geisinger E. Quorum sensing in staphylococci. Annu Rev Genet. 2008:42(1):541-64.

8. Viegas SC, Arraiano CM. Regulating the regulators: how ribonucleases dictate the rules in the control of small non-coding RNAs. RNA Biol. 2008; 5(4):230-43.

9. Chao Y, Papenfort K, Reinhardt R, Sharma CM, Vogel J. An atlas of Hfqbound transcripts reveals $3^{\prime}$ UTRs as a genomic reservoir of regulatory small RNAs. EMBO J. 2012;31(20):4005-19.

10. Göringer M, Hartmann RK. 3'-UTRs as a source of regulatory RNAs in bacteria. EMBO J. 2012;31(20):3958-60.

11. Clancy S. RNA Functions. 2018;1:1-5.

12. Crick FH. Central dogma of molecular biology. Nature. 1970;227(6):561-3.

13. Sansen J, Thébault P, Dutour I, Bourqui R. Visualization of sRNA-mRNA interaction predictions. Proc Int Conf Inf Vis. 2016;2016:342-7.

14. Lagos-Quintana M, Rauhut R, Lendeckel W, Tuschl T. Identification of novel genes coding for RNAs of small expressed RNAs. Science (80- ). 2001; 294(5543):853-8.

15. W, Zhong., G, Mark. et al. RNA-Seq : a revolutionary tool for transcriptomics. Narure Rev Genet. 2015;10:57-63.

16. Li W, Ying X, Lu Q, Chen L. Predicting sRNAs and their targets in Bacteria. Genomics Proteomics Bioinforma. 2012;10(5):276-84.

17. Tjaden B, Goodwin SS, Opdyke JA, Guillier M, Fu DX, Gottesman S, et al. Target prediction for small, noncoding RNAs in bacteria. Nucleic Acids Res. 2006:34(9):2791-802.

18. Landgraf P, Rusu M, Sheridan R, Sewer A, lovino N, Aravin A, et al. A mammalian microRNA expression atlas based on small RNA library sequencing. Cell. 2007;129(7):1401-14.

19. Soper T, Mandin P, Majdalani N, Gottesman S, S a W. Positive regulation by small RNAs and the role of Hfa. Pnas. 2010;107(21):2-7.

20. Caldelari I, Chao YY, Romby P, Vogel J. RNA-Mediiated regulation in pathogenic Bacteria. Cold Spring Harb Perspect Med. 2013;3(9):1-22

21. McCullen CA, Benhammou JN, Majdalani N, Gottesman S. Mechanism of positive regulation by DsrA and RprA small noncoding RNAs: pairing increases translation and protects rpoS mRNA from degradation. J Bacteriol. 2010;192(21):5559-71.

22. Beisel $\mathrm{CL}$, Storz G. Base pairing small RNAs and their roles in global regulatory networks. FEMS Microbiol Rev. 2010;34(5):866-82.

23. Gottesman S, Storz G. Bacterial small RNA regulators : versatile roles and rapidly evolving variations; 2018.

24. Moller T, Franch T, Hojrup P, Keene DR, Bächinger HP, Brennan RG, et al Hfa: a bacterial Sm-like protein that mediates RNA-RNA interaction. Mol Cell. 2002;9(1):23-30

25. Vogel J, Luisi BF. Hfq and its constellation of. RNA. 2015;9(8):578-89.

26. Brittain RT, Farmer JB, Jack D, Martin LE, Simpson WT. Factor fraction required for the synthesis of bacteriophage Qbeta-RNA. Nature. 1968; 219(5156):862-3.

27. Wagner EGH, Romby P, Small RNAs in bacteria and archaea: who they are, what they do, and how they do it, Ch 3. Advances in Genetics, Academic Press, Volume 90, 2015. p. 133-208.

28. Michaux C, Verneuil N, Hartke A, Giard J-C. Physiological roles of small RNA molecules. Microbiology. 2014;160(Pt_6):1007-19.

29. Sedlyarova N, Shamovsky I, Bharati BK, et al. sRNA-Mediated control of transcription termination in E. coli. Cell. 2016;167(1):111-121.e13. 
30. Rutherford ST, Van KJC, Shao Y, Bassler BL. vibrios AphA and LuxR / HapR reciprocally control quorum sensing in vibrios; 2011. p. 397-408.

31. Li J, Attila C, Wang L, Wood TK, Valdes JJ, Bentley WE. Quorum sensing in Escherichia coli is signaled by Al-2/LsrR: effects on small RNA and biofilm architecture. J Bacteriol. 2007;189(16):6011-20.

32. Gu H, Zhao C, Zhang T, Liang H, Wang XM, Pan Y, et al. Salmonella produce microRNA-like RNA fragment Sal-1 in the infected cells to facilitate intracellular survival. Sci Rep. 2017;7(1):1-12.

33. Tesorero RA, Yu N, Wright JO, Svencionis JP, Cheng Q, Kim JH, et al. Novel regulatory small RNAs in Streptococcus pyogenes. PLoS One. 2013;8(6).

34. Le Rhun A, Beer YY, Reimegård J, Chylinski K, Charpentier E. RNA sequencing uncovers antisense RNAs and novel small RNAs in Streptococcus pyogenes. RNA Biol. 2016;13(2):177-95.

35. Pappesch R, Warnke P, Mikkat S, Normann J, Wisniewska-Kucper A, Huschka $F$, et al. The regulatory small RNA MarS supports virulence of Streptococcus pyogenes. Sci Rep. 2017;7(1):1-15.

36. Timmermans J, Van Melderen L. Post-transcriptional global regulation by CsrA in bacteria. Cell Mol Life Sci. 2010;67(17):2897-908.

37. Visick KL. Layers of Signaling in a Bacterium Host Association. 2015;187(11):3603-6.

38. Nealson $\mathrm{KH}$, Hastings JW. Bacterial bioluminescence: its control and ecological significance. Microbiol Rev. 1979;43(4):496-518.

39. Eberhard A, Burlingame AL, Eberhard C, Kenyon GL, Nealson KH, Oppenheimer NJ. Structural identification of autoinducer of Photobacterium fischeri luciferase. Biochemistry. 1981;20(9):2444-9.

40. Hastings J, Greenberg EP. Quorum sensing: the explanation of a curious phenomenon reveals a common characteristic of bacteria. J Bacteriol. 1999; 181(9):2667-8.

41. Miller MB, Bassler BL. Quorum sensing in Bacteria. Annu Rev Microbiol. 2001; 55(1):165-99.

42. Rutherford ST, Bassler BL. Bacterial quorum sensing: its role in virulence and possibilities for its control. Cold Spring Harb Perspect Med. 2012;2(11):1-26.

43. Whitehead NA, Barnard AML, Slater H, Simpson NJL, Salmond GPC. Quorum-sensing in Gram negative bacteria. FEMS Microbiol Rev. 2001;25(4): 365-404.

44. More M, Finger LD, Stryker UL, Fuqua C, Eberhard A, Winans SC. Enzymatic synthesis of a quorum-sensing autoinducer through use of defined substrates. Science (80- ). 1996:272(June):1655-8.

45. Xavier KB, Bassler BL. Regulation of uptake and processing of the quorum-sensing autoinducer Al-2 in Escherichia coli. J Bacteriol. 2005; 187(1):238-48

46. Papenfort K, Bassler BL. Quorum sensing signal-response systems in gramnegative bacteria. Nat Rev Microbiol. 2016;14(9):576-88.

47. Hentzer M, Wu H, Andersen JB, Riedel K, Rasmussen TB, Bagge N, et al. Attenuation of Pseudomonas aeruginosa virulence by quorum sensing inhibitors. EMBO J. 2003;22(15):3803-15.

48. Papenfort K, Bassler B, Chase C. Quorum sensing signal- Rsponse Systems in Gram-Negative Bacteria. Nat ev Microbiol. 2017;14(9):576-88.

49. Heeb S, Haas D. Regulatory roles of the GacS / GacA two-component system in plant-associated and other gram-negative Bacteria. Mol PlantMicrobe Interact. 2001;14(12):1351-63.

50. Anetzberger C, Reiger M, Fekete A, Schell U, Stambrau N, Plener L, et al. Autoinducers act as biological timers in Vibrio harveyi. PLoS One. 2012;7(10).

51. Schaefer AL, Hanzelka BL, Eberhard A, Greenberg EP. Quorum sensing in Vibrio fischeri: probing autoinducer-LuxR interactions with autoinducer analogs. J Bacteriol. 1996;178(10):2897-901.

52. Fuqua C, Winans SC, Greenberg EP. CENSUS AND CONSENSUS IN BACTERIAL ECOSYSTEMS: the LuXR-LuXI family of quorum-sensing transcriptional regulators. Annu Rev Microbiol. 1996;50(1):727-51.

53. Choi SH, Greenberg EP. The C-terminal region of the Vibriofischeri LuxR protein contains an inducer-independent lux gene activating domain (luninescence/transcriptional activation/DNA-binding domain/repression). Genetics. 1991;88(December):11115-9.

54. Koch B, Liljefors T, Persson T, Nielsen J, Kjelleberg S, Givskov M. The LuxR receptor: the sites of interaction with quorum-sensing signals and inhibitors. Microbiology. 2005;151(11):3589-602.

55. Smith RSIB. Pseudomonas aeruginosa quorum sensing as a potential antimicrobial agent. J Clin Invest. 2003;112(10):1460-5.

56. Kleerebezem M, Quadri LEN, Kuipers OP, De Vos WM. Quorum sensing by peptide pheromones and two-component signal- transduction systems in gram-positive bacteria. Mol Microbiol. 1997;24(5):895-904.
57. Monnet V, Gardan R. Quorum-sensing regulators in gram-positive bacteria: "cherchez le peptide". Mol Microbiol. 2015;97(2):181-4.

58. Personnic N, Striednig B, Hilbi H. Legionella quorum sensing and its role in pathogen-host interactions. Curr Opin Microbiol. 2018:41:29-35.

59. Abbamondi GR. The role of quorum sensing in marine bacteria, archaea and inter-kingdom communication; 2013.

60. Lowery CA, Dickerson TJ, Janda KD. Interspecies and interkingdom communication mediated by bacterial quorum sensing. Chem Soc Rev. 2008;37(7):1337-46.

61. Lihui Feng, Steven T. Rutherford, Kai Papenfort, John D. Bagert JC van, Kessel, David A. Tirrell, Ned S. Wingreen, and Bonnie L. Bassler. A Qrr non-coding RNA deploys four different regulatory mechanisms to optimize quorum-sensing dynamics. J Biomed Mater Res A. 2011;96(3):1-27.

62. Tsatsaronis JA, Franch-Arroyo S, Resch U, Charpentier E. Extracellular vesicle RNA: a universal mediator of microbial communication? Trends Microbiol. 2018;26(5):401-10

63. Choi JW, Um JH, Cho JH, Lee HJ. Tiny RNAs and their voyage via extracellular vesicles: secretion of bacterial small RNA and eukaryotic microRNA. Exp Biol Med. 2017;242(15):1475-81.

64. Kuehn MJ, Kesty NC. Bacterial outer membrane vesicles and the host pathogen interaction. Genes Dev. 2005;(Beveridge 1999):2645-55.

65. Kulp A, Kuehn MJ. Biological functions and biogenesis of secreted bacterial outer membrane vesicles. Annu Rev Microbiol. 2010;64(1):163-84.

66. Lambertz U, Oviedo Ovando ME, Vasconcelos EJR, Unrau PJ, Myler PJ, Reiner NE. Small RNAs derived from tRNAs and rRNAs are highly enriched in exosomes from both old and new world Leishmania providing evidence for conserved exosomal RNA packaging. BMC Genomics. 2015;16(1).

67. Chen X, Liang H, Zhang J, Zen K, Zhang CY. Secreted microRNAs: a new form of intercellular communication. Trends Cell Biol. 2012;22(3):125-32.

68. Zhou G, Zhou Y, Chen X. New insight into inter-kingdom communication: horizontal transfer of mobile small RNAs. Front Microbiol. 2017:8(MAY):1-9.

69. Gottesman S, Storz G. Bacterial small RNA regulators: versatile roles and rapidly evolving variations. Cold Spring Harb Perspect Biol. 2011;3(12):1-16.

70. Han L, Luan Y-S. Horizontal transfer of small RNAs to and from plants. Front Plant Sci. 2015;6(December):1-7.

71. Al-Nedawi K, Mian MF, Hossain N, Karimi K, Mao YK, Forsythe P, et al. Gut commensal microvesicles reproduce parent bacterial signals to host immune and enteric nervous systems. FASEB J. 2015;29(2):684-95.

72. Nowotny A, Behling UH, Hammond B, Lai CH, Listgarten M, Pham PH, et al. Release of toxic microvesicles by Actinobacillus actinomycetemcomitans. Infect Immun. 1982;37(1):151-4

73. Lee EY, Choi DY, Kim DK, Kim JW, Park JO, Kim S, et al. Gram-positive bacteria produce membrane vesicles: proteomics-based characterization of Staphylococcus aureus-derived membrane vesicles. Proteomics. 2009;9(24): 5425-36.

74. Resch U, Tsatsaronis JA, Le Rhun A, Stübiger G, Rohde M, Kasvandik S, et al. A two-component regulatory system impacts extracellular membrane-derived vesicle production in group a streptococcus. MBio. 2016;7(6):1-10.

75. Schwechheimer C, Kuehn MJ. Outer-membrane vesicles from gramnegative bacteria: biogenesis and functions. Nat Rev Microbiol. 2015 13(10):605-19.

76. Sjöström AE, Sandblad L, Uhlin BE, Wai SN. Membrane vesicle-mediated release of bacterial RNA. Sci Rep. 2015:5:1-10.

77. Guerrero-Mandujano A, Hernández-Cortez C, Ibarra JA, Castro-Escarpulli G. The outer membrane vesicles: secretion system type zero. Traffic. 2017;18(7): 425-32.

78. Knip M, Constantin ME, Thordal-Christensen H. Trans-kingdom cross-talk: small RNAs on the move. PLoS Genet. 2014;10(9).

79. Koeppen K, Hampton TH, Jarek M, Scharfe M, Gerber SA, Mielcarz DW, et al. A novel mechanism of host-pathogen interaction through sRNA in bacterial outer membrane vesicles. PLoS Pathog. 2016;12(6):1-22.

80. Harris JF, Micheva-Viteva S, Li N, Hong-Geller E. Small RNA-mediated regulation of host-pathogen interactions. Virulence. 2013;4(8).

81. Heijtz RD, Wang S, Anuar F, Qian Y, Bjorkholm B, Samuelsson A, et al. Normal gut microbiota modulates brain development and behavior. Proc Natl Acad Sci. 2011;108(7):3047-52.

82. El Andaloussi S, Mäger I, Breakefield XO, Wood MJA. Extracellular vesicles: biology and emerging therapeutic opportunities. Nat Rev Drug Discov. 2013;12(5):347-57. 
83. Archambaud C, Sismeiro O, Toedling J, Soubigou G, Bécavin C, Lechat P, et al. The intestinal microbiota interferes with the microrna response upon oral listeria infection. MBio. 2013;4(6):1-10.

84. Zhang L. Gene expression profiles in Normal and Cancer cells. Science (80- ). 1997;276(5316):1268-72.

85. Jiang L, Vader P, Schiffelers RM. Extracellular vesicles for nucleic acid delivery: Progress and prospects for safe RNA-based gene therapy. Gene Ther. 2017;24(3):157-66.

Ready to submit your research? Choose BMC and benefit from:

- fast, convenient online submission

- thorough peer review by experienced researchers in your field

- rapid publication on acceptance

- support for research data, including large and complex data types

- gold Open Access which fosters wider collaboration and increased citations

- maximum visibility for your research: over $100 \mathrm{M}$ website views per year

At $B M C$, research is always in progress.

Learn more biomedcentral.com/submissions 